Volume 1, Number 1 (2021)

\title{
Spiel (Play, Game)
}

\section{Patricia A. Simpson}

To cite this article: Simpson, Patricia A. "Spiel (Play, Game)." Goethe-Lexicon of Philosophical Concepts, no 1 (2021): 83-98.

To link to this article: https://doi.org/10.5195/glpc.2021.29

Published by the University Library System, University of Pittsburgh.

\section{(c)}

Entries in this Lexicon are licensed under a Creative Commons Attribution 4.0 United States License.

Copyright $\odot$ the Author(s). 


\section{Spiel (Play, Game)}

By positioning the vita activa between homo faber (man the maker) and homo ludens (man the player), Goethe's concept of Spiel captures the existential, aesthetic, and philosophical instability in the human condition. Himself a master of play and the game, Goethe broadened the semantic field of the concept by projecting it onto tensions associated with his early verbal, visual, and corporeal quest for pleasure and beauty. As such, Spiel is situated in Goethe's philosophical lexicon at the nexus of the aesthetic and the practical (including the ethical). This position locates the writer biographically as well: his professional court life and his creative project, including his scientific work, are precariously balanced between the imaginative and the mundane.

Spiel as a philosophical concept also reflects Goethe's lifelong performance of multiple identities, manifest in rehearsals of bohemian and bourgeois masculinity. Not least, his life and work express a personal and professional relationship to an eighteenth-century environment articulated as a quasi-religious devotion to the forces of nature. Closely related to concepts of fate, divine agency, and luck, Goethe's gift for play would craft and stage a series of Schauspiele (shows), Lustspiele (comedies), and Trauerspiele (mourning plays) that ultimately equipped his concept of Spiel to do philosophical work. Both literally and figuratively a player, Goethe constructed dynamic models of Spiel as gambling across a range of practices and activities that include play as magic (Taschenspieler); pedagogical games; children's play and amusement; acting (eine Rolle spielen); and personal and social role playing. And while play maintained a relationship to labor and accountability throughout the writer's life, the serious philosophical work of Goethean Spiel also typically involved the disruption of rigid systems of thought that purport to defy the precarious stability of being human.

\section{Introduction}

The opposition between homo faber (man the maker) and homo ludens (man the player) obtains in Goethe's lexicon of philosophical concepts, as it does for his age. In his life and work, however, Goethe persistently probed the limits and permutations of that binary, transforming play into work and work into play. With the concept and practice of Spiel, he speculatively expanded the range of play and games. And while Immanuel Kant's philosophy had advanced the significance of the aesthetic, along with its construction of the imagination as a critical and creative faculty that is the source of free play, Goethe would reconsider and reconceptualize the role of the Kantian imagination with respect to play. Beyond Kant, however, and his uncontainable impulse to forge connections between cognition (dominated by reason and the understanding), on the one hand, and the affects and the body (through sen- sory perception) on the other, Goethe disrupts regulatory systems whenever the concepts (or experience) of pleasure and creation are engaged. Personally and professionally acquainted with many prominent philosophers of his time, particularly those associated with German Idealism-e.g., Johann Gottlieb Fichte (1762-1814) and Georg Wilhelm Friedrich Hegel (1770-1831) - Goethe developed a concept of Spiel more in dialogue with contemporary aesthetic theorists like Friedrich Schlegel and his circle, who, together with the Athenaeum editors, connected the Idee (idea) to literature and advanced a theoretical position that featured it as essentially incomplete.

The subsequent theorizing of a Spieltrieb (play drive), most prominently in Friedrich Schiller's Über die ästhetische Erziehung des Menschen in einer Reihe von Briefen (1795-96; On the Aesthetic Education of the Human Being in a Series of Letters), prompts revisiting the full range of texts where Goethe deploys Spiel beyond the important lyrical example 
Philosophy at Play: In the final section of Der Begriff der Kunstkritik in der deutschen Romantik (1919; The Concept of Art Criticism in German Romanticism), ' Walter Benjamin would subsequently suggest how the aesthetic position of the early romantic theorists differed from Goethe's position and that of early Weimar Classicism, which (under the influence of F. W. J. Schelling) explored the philosophical potential of play to mediate between form and content or the ideal and its manifestation. Schelling, who according to Slavoj Žižek, stands at the forefront of German materialist thought, specifically reconceptualized evil so that it exceeds the Hegelian problematic: "Hegel reduces Evil to the subordinated moment in the self-mediation of Idea qua supreme good, whereas in Schelling Evil remains a permanent possibility which can never be fully 'sublated [aufgehoben]' in and by Good." "ii Goethe, who would use a number of playful Mephistophelean interventions in Faust I and Faust II to reinvent the subject-object dialectic, appears to have been moving in the same direction. Both lines of thought intersect in how they understand the literary work of art. Focusing on the relationship between fragment and totality, Philippe Lacoue-Labarthe and Jean-Luc Nancy conclude that "the identity of philosophy and literature and of literature and philosophy [. . . ] never takes place [again]" although marginally, they place Goethe in opposition to the Schlegels. iii

i. Walter Benjamin, "Die frühromantische Kunsttheorie und Goethe," in Der Begriff der Kunstkritik in der deutschen Romantik. Abhandlungen, Gesammelte Schriften, eds. Rolf Tiedemann and Hermann Schweppenhäuser (Frankfurt a.M.: Suhrkamp, 1991), 1.1:110-22.

ii. Slavoj Žižek, The Indivisible Remainder: On Schelling and Related Matters (London: Verso, 1996), 6.

iii. See Philippe Lacoue-Labarthe and Jean-Luc Nancy, The Literary Absolute: The Theory of Literature in German Romanticism, trans. Philip Barnard and Cheryl Lester (Albany: SUNY Press, 1988), 123. On the relationship between philosophical and literary writing in Nietzsche, see Paul de Man, "Action and Identity in Nietzsche," Yale French Studies 52 (1975): 16-30. Here de Man links literary and philosophical discourse in Nietzsche's work through his critique of concepts such as truth and goodness: "Nietzsche's work raises the perennial question of the distinction between philosophy and literature by way of a deconstruction of the value of values" (16).

of the "Erlkönig" (1782; Elfking), which Pierre Bertaux has interpreted through the line "Gar schöne Spiele spiel' ich mit dir" (FA 1.1:304; Such lovely games I will play with you). Bertaux maps a broad semantic field of Goethean play by including tomfoolery and pranks (Tor- and Tollheiten, as well as Streiche and Eulenspiegeleien); theatrical and puppet play performances (Schauspiele and Puppenspiele); existential masking and the play with identity (Kostümierungen, Masken, and Bälle); and the celebratory or festival play (Festspiel) such as the theater of war and market festivals. ${ }^{1}$ In addition to extending the conceptual and speculative range of Spiel to the central wager or gamble with the high stakes of the human soul in Faust, Bertaux claims that Goethe's latus absconditum (hidden side) "can be characterized with the single word play" (läßt sich mit einem Wort bezeichnen: dem Wort Spiel). ${ }^{2}$ And while this assertion may seem exaggerated, careful consideration of the semantic range of Spiel in Goethe's work and life suggests that the poet's "playful" side is not so well-hidden.

Within its conceptual hierarchy, Goethean Spiel functions in a number of ways. First, as constitutive of the tension between life and spectacle, it connects the leisure of diversion to existential catastrophe. Second, as performance, it links the internal conditions of existence with its external forms, including the exemplary pedagogy of instruction that acts of play - as Beispiele (examples) - exhibit. Third, when reconfigured in the evolving representation of the play drive, Spiel expresses the vicissitudes of desire and emotion. And fourth, like other Goethean concepts, Spiel attacks orthodoxies by disrupting the systematic and sacrosanct. As employed by Goethe in literature, then, Spiel typically challenges the presumed rigor of systematic philosophy.

In historical context, Spiel is infrequently elevated to the status of a concept. ${ }^{3}$ Instead, and especially around 1800 , its impulses are inscribed into the mechanics of negation and irony and then recuperated in a dialectical sublation generally associated with Hegelian Aufhebung. Goethe's concept departs from this philosophical model. Occupied at the time with its relation to the traditional conceptual problems of theology, German philosophical thought focused on metaphysics, which was emerging as a disciplinary practice within institutions like the modern university. Here an ascending nationalist sentiment also reinforced tensions with French philosophical models, which in turn complemented the tendency of middle-class subjectivity to question theological orthodoxies. In this context, Goethe's legal background and subsequent administrative work at the Weimar court brought him into direct contact, and sometimes 
conflict, with philosophical innovators like Fichte, whose radical new version of transcendental idealism and human subjectivity crossed the writer's path and occasioned bureaucratic intervention. In a letter written to Voigt on April 10,1795 , Goethe sardonically shared his skepticism about Fichte's absolute subject and the upheavals at the University of Jena, which were connected to the philosopher's atheism: "Sie haben also das absolute Ich in großer Verlegenheit gesehen und freylich ist es von den Nicht-Ichs, die man doch gesetzt hat, sehr unhöflich durch die Scheiben zu fliegen" (FA 2.4:65; So they have seen the great embarrassment of the absolute I and, of course, it is very impolite of the Not-I's that have been posited to fly through the windows). ${ }^{4}$ With obvious knowledge of Fichte's plight, Goethe playfully turns the posited objects onto the author of the absolute subject, ironizing the theoretical at his expense. And his skeptical attitude toward Naturphilosophie (natural philosophy) would express itself, along similar lines, both in Faust, his most philosophical literary work, and other texts that repeatedly question the possibility of achieving the speculative unity of Natur and Geist (nature and mind or spirit). Despite his resistance to the systematic philosophy of Kant and the post-Kantians, however, Goethe was able to construct Spiel as a recurring philosophical concept throughout the course of his long creative life. ${ }^{5}$

Johan Huizinga's Homo Ludens: A Study of the Play Element in Culture (1938) represents one significant scholarly contribution to the categorization of human beings not only as makers (homo faber), but also as players (homo ludens). ${ }^{6} \mathrm{By}$ dismantling the presumed opposition between play and seriousness, Huizinga's narrative came to encompass an unusually broad range of cultural and aesthetic practices that, according to Thomas Henricks, understood that "civilization, at least in its earliest stages, is performed or played" (Henricks, Play and the Human Condition, 2). ${ }^{7}$ Huizinga's expansive view of performative play encompasses the creative impulses associated with poetry, music, and dance. Few studies, however, including Homo Ludens, examine the concept of play from a philosophical viewpoint. And while cultural histories of play, inclusive of found objects, reconstructions from literature, the visual arts, clothing, the decorative arts, and extant books and diaries can be found for single authors, a systematic treatment of Goethe's concept of play in its historical-philosophical context still needs to be written. ${ }^{8}$

Kant's Kritik der Urteilskraft (1790; Critique of the Power of Judgment) defines the play act-in contrast to labor, "which on its own account is disagreeable"-as an "occupation that is agreeable on its own account." Friedrich Schiller (1759-1805), who helped to popularize Kantian philosophy, devotes significant attention to the human aspect of play in his Über die ästhetische Erziehung der Menschen. Schiller's treatise, which engages with Kant's aesthetics, as well as the French Revolution and its aftermath, analyzes the concept of the play drive in terms the reciprocal relationship between affect and sensuousness, on the one hand, and rationality, on the other. In aesthetic play, he argues human beings become truly human:

Der Spieltrieb also, als in welchem beide verbunden wirken, wird das Gemüth zugleich moralisch und physisch nöthigen; er wird also, weil er alle Zufälligkeit aufhebt, auch alle Nötigung aufheben und den Menschen, sowohl physisch als moralisch, in Freiheit setzen. Wenn wir jemand mit Leidenschaft umfassen, der unsrer Verachtung würdig ist, so empfinden wir peinlich die Nötigung der Natur. Wenn wir gegen einen andern feindlich gesinnt sind, der uns Achtung abnötigt, so empfinden wir peinlich die Nötigung der Vernunft. Sobald er aber zugleich unsre Neigung interessiert und unsre Achtung sich erworben, so verschwindet sowohl der Zwang der Empfindung als der Zwang der Vernunft, und wir fangen an, ihn zu lieben, d.h. zugleich mit unsrer Neigung und mit unsrer Achtung zu spielen. ${ }^{10}$

The play-drive, in consequence, as the one in which both the others act in concert, will exert upon the psyche at once a moral and a physical constraint; it will, therefore, since it annuls all contingency, annul all constraint too, and set man free both physically and morally. When we embrace with passion someone who deserves our contempt, we are painfully aware of the compulsion of nature. When we feel hostile toward another who compels our esteem, we are painfully aware of the compulsion of reason. But once he has at the same time engaged our affection and won our esteem, then both the compulsion of feeling and the compulsion of reason disappear and we begin to love him, i.e., we begin to play with both our affection and esteem. (Schiller, On the Aesthetic Education of Man, 97) 
Schiller's play impulse, also known as the play drive, originates between the sensuous and the formal drives. Yet the drive and its reception develop away from actual play. In the fifteenth letter, Schiller qualifies the sphere of the play drive and its influence:

Freilich dürfen wir uns hier nicht an die Spiele erinnern, die in dem wirklichen Leben im Gange sind und die sich gewöhnlich nur auf sehr materielle Gegenstände richten; aber in dem wirklichen Leben würden wir auch die Schönheit vergebens suchen, von der hier die Rede ist. Die wirklich vorhandene Schönheit ist des wirklich vorhandenen Spieltriebes wert; aber durch das Ideal der Schönheit, welches die Vernunft aufstellt, ist auch ein Ideal des Spieltriebes aufgegeben, das der Mensch in allen seinen Spielen vor Augen haben soll. (Schiller, On the Aesthetic Education of Man, 106)

True, we must not think here of the various forms of play which are in vogue in actual life, and are usually directed to very material objects. But then in actual life we should also seek in vain for the kind of beauty with which we are here speaking. The beauty we find in actual existence is precisely what the play-drive we find in actual existence deserves; but with the ideal of Beauty that is set up by Reason, an ideal of the play-drive, too, is enjoined upon man, which he must keep before his eyes in all his forms of play. (Schiller, On the Aesthetic Education of Man, 107)
Here we can see how Schiller's explicit and Goethe's implicit theory of human play and games diverge. While Schiller is unconcerned with games currently in vogue, Goethe extends the theoretical range and influence of play, especially when real and material objects are a factor. The philosophical implications of this important difference in disposition come to the fore in Schiller's letter to Goethe on July 8, 1796, where (in a rhetorical move reminiscent of the "Court of Reason" in Kant's first critique) he calls on the dramatist explicitly to legitimize his imaginative play in front of Reason itself:

Es wäre also bloß nöthig, jene theatralischen Vorfälle, die er (der Leser) nur als ein Spiel der Imagination ansehen möchte, durch eine deutlicher ausgesprochene Beziehung auf den höchsten Ernst des Gedichtes, auch vor der Vernunft zu legitimieren. ${ }^{11}$

It would therefore be merely necessary to legitimize before Reason those theatrical incidents that he [the reader] might regard just as a play of the imagination, through a more clearly pronounced relationship to the highest seriousness of the poem.

Schiller's pronouncement prescribes the moral significance of his aesthetics by insisting on the public accountability of the theater. For Goethe, by contrast, the "play" of the imagination with the idea came to constitute the aesthetic moment itself.

The Sublime: Kant's third critique, along with Schiller's interpretation of its discussion of the power of the aesthetic judgment, remain important parts of a diverse philosophical legacy for Goethe that connects play not only with theories of the beautiful, but also with theories of the sublime. While writing from Rome about his recent trip to Naples, for example, where he observed an eruption of Vesuvius from a distance, Goethe describes the volcanic spectacle in terms that clearly echo Kant's discussion of the "dynamically sublime" in $\S 28$ of the third critique as a natural power "with no dominion over us." Like his Kantian counterpart in the face of cliffs, thunder clouds, hurricanes, volcanoes, Goethe - one might infercould entertain a sense of his moral superiority over nature's raw power, because, as he recalls in a letter on June 8, 1783, he had observed it from a position of safety: "So hab ich denn dieses Naturschauspiel, obgleich nur von weitem gesehn" (WA 4.8:229; thus I saw this spectacle [play, display, show] of nature, although only from afar).

i. Johann Wolfgang von Goethe, Rom, d. 8. Juni. Briefe an Charlotte von Stein, 1783 1786. The source for quotations not available in the FA is the Weimar Edition (WA): Goethes Werke. Herausgegeben im Auftrage der Großherzogin Sophie von Sachsen, 40 vols. (Weimar: Hermann Böhlau), 1887-1919. 
An important resource for a number of wide-ranging definitions of Spiel is Grimms' dictionary, which is rife with examples from Kant, Schiller, and Goethe. Unlike lexicon entries, however, even dictionaries as comprehensive as Grimms' do not consider interpretive context when citing literary and philosophical sources. But at least one grammatical consideration can be instructive when analyzing the lexeme Spiel as a verb: play is both transitive and intransitive. One can play something as well as play. That is to say, Spiel can imply an agency attributed variously to human and divine forces, as we can see in a citation in the dictionary from Goethe in which the noun "play" obscures memory:

[I]ndem ich nun aber darauf sinne, was wohl zunächst weiter mitzutheilen wäre, so kommt mir durch ein seltsames Spiel der Erinnerung, das ehrwürdige Münstergebäude wieder in die Gedanken. $^{12}$

But now that I consider what should be communicated first, the venerable cathedral enters my thoughts through a strange play of memory.

Interestingly, Goethe's comment about the Strasbourg Cathedral puts two genitive constructions - the play of memory and the memory of play-in reciprocal relation to each other, thereby marking Spiel as a structure of thought that, additionally understood as a process, is tensed both forward and backward. A similar construction in Kant's first critique, however, also cited in the Grimms' Wörterbuch - " 'das ganze dialektische Spiel der kosmologischen Ideen'" (1781; the entire dialectical play of cosmological ideas) - puts a form of intelligibility (idea) in dialectical relation with play, so that it acquires a kind of transcendental (or at least regulative) status in the production of the universal idea. ${ }^{13}$ But in each of these examples, Spiel, as the play of memory, imagination, or ideas, on the one hand, and the memory of play, on the other, performs within the grammar of the subjective/objective genitive, where agency remains ambiguous. Within their aesthetic register, moreover, Goethe's various usages of Spiel-in word play, rhyme, or even the synesthetic play/display of color generation called Farbenspiel in the poem "Wiederfinden" (FA 1.3:97; 1819; Reunion) - closely connect play, as a philosophical concept, to the exuberant life of all self-generating forms.

This poem, which connects human creativity with the divine act of cosmological creation, provides an instructive example of how, within the conceptual field of play, Goethe rethinks orthodox notions of God in order to rethink natural processes and, by implication, science as well. Here the poet imagines God's solitude while the silent labor of his creation is filled with the "erklingend Farbenspiel" (FA 1.3:97; resounding play of colors) of the goddess Dawn. ${ }^{14}$ The creative "play of colors" that accompanies the rising sun in turn connects Spiel to scientific investigation as elaborated in Goethe's color theory and optics. ${ }^{15}$ And while this play can be excessive and so disparaged, it can also enliven and clarify natural processes. Once we realize "[d]aß durch Verbindung der Gegensätze das Spektrum erst entsteht" (WA 2.4:485; that the full spectrum of color is produced through the connection of opposites), Goethe explains, we will also recognize "daß hier eine Polarität im Spiele sei" (WA 2.4:485; that a polarity is in play here). Elsewhere, Goethe connects the optics of polarity to the aesthetic experience of Faust in the act of observing the rainbow created by falling water, which he associates, in the opening scene of Faust II, with human striving: "Ihm sinne nach, und du begreifst genauer; / Am farbigen Abglanz haben wir das Leben" (FA 1.7:206.4726-27; Reflect upon it, and you will grasp more precisely; / We experience life in refracted color).

As the polarity "in play" leads to further reflection on the relationship between surfaces, Goethe expands the sematic range of Spiel by attributing a form of life to it that (like Spinoza's modes) also expresses the infinite generative productivity of the divine substance. In the study of optics and color theory, regarding the number of colors, Goethe writes:

Bedenkt man ferner was die schillernden oder sonst wechselnden Widerscheine für eine unendliche Mannigfaltigkeit in die Oberflächen bringen, was sonst für Zufälligkeiten bei andern farbigen Naturphänomenen obwalten können; so sieht man recht gut, daß hier nicht von Zahl, sondern von einem unendlich lebendigen Spiel die Rede sein könne. (WA 2.5:17)

If one further considers what kind of infinite plurality the shimmering or otherwise shifting reflections bring to the surface, what other coincidences can prevail in other colorful natural phenomena: then one can clearly see that we can speak not of a number, but rather of an infinitely living game.

It is not only as scientist, however, but also as aesthetic theorist, poet, painter, and occasionally prankster, that Goethe identifies play with an agency that exceeds what 
the mind can measure or quantify. That is to say, whether scientific, aesthetic, cosmological, or natural, Goethean Spiel organizes cognitive, imaginative, and material processes without recourse to numbers. However unsystematic his engagements with play might seem at first glance, therefore, by exploiting its ambiguities, he also reveals an existential and philosophical seriousness in Spiel by repeatedly performing it, which finally means staging play self-consciously playing its own game.

\section{Spiel as a Philosophical Concept}

In a number of his literary works, as well as in descriptions of natural spectacle and accounts of historical violence, Goethe explores the figurative capacity of Spiel that the second definition in Adelung's Wörterbuch der hochdeutschen Mundart (1793-1801; Dictionary of the High-German Language) equates with motion and activity. Often filtered through Kant's aesthetics of the sublime, such workswhich stage optics as performance-typically forge connections between wide-ranging subjective experiences of the visible world and outside forces. Some twenty instances of the lexeme Spiel, for example, including several of its earliest configurations as visual experience, can be found in Goethe's first novel, Die Leiden des jungen Werthers (1774; The Sufferings of Young Werther), whose protagonist perceives the world through the eyes of an artist and alienated lover. Significantly, Werther's first encounter with Lotte as recorded in his letter of June 16 is metaphorically configured as a play, or show:
Ich ging durch den Hof nach dem wohlgebauten Hause, und da ich die vorliegenden Treppen hinaufgestiegen war und in die Tür trat, fiel mir das reizendste Schauspiel in die Augen, das ich je gesehen habe. (FA 1.8:41)

I walked across the courtyard to a well-built house, and, when I had ascended the flight of steps in front and opened the door, the most charming spectacle [play] that I had ever seen struck my eye. ${ }^{16}$

Werther's account of his visit to Lotte's bucolic home immediately stages his very first glimpse of her as a dramatic tableaux of country domesticity that, as a privileged spectator or even voyeur, he can enjoy. With his gaze soon arrested, however, the erstwhile spectator of this reizende (meaning charming, fetching, or stimulating) Schauspiel (meaning play, spectacle, show, or display) himself mounts its stage. Together with the young woman whose simple white dress with pink ribbons had first caught his gaze, then, Goethe's tragic protagonist finds himselfboth literally and figuratively-frozen with her in an intimate mise-en-scène, or "show" (also play, Schauspiel) of his own making.

Shortly thereafter, Werther accompanies Lotte to the famous country dance, where as his partner she "fetchingly" and "fleetingly" moves along with gracefully outstretched arms - "Mit welchem Reize, mit welcher Flüchtigkeit bewegte sie sich!" (FA 1.8:49; with what excitement, what fleetingness she propelled herself)—only

Erotic Games: In his suggestive analysis of Goethe's play drive, Pierre Bertaux devotes a full chapter to erotic games. His biographically framed account, which details the writer's sexual attractions and their sublimations as literature, moves from Weimar to Milan and back, with Christiane Vulpius's appearance in the narrative serving as a game changer. Brian Sutton-Smith's classic study of the ambiguity of language in theorizing the "play sphere" expands Bertaux's conceptual field by returning to Goethe's family constellation in Frankfurt and re-centering his interest in play to include childhood interactions with toys and games. Sutton-Smith writes in a generous way about these practices, which breached the boundaries between the childhood world of play and adult enterprises: "Sexual intimates are said to play with each other in innumerable ways, painting each other's bodies, [eating food off of each other, playing hide the thimble in bodily crevices,] and, in general, testing each other with playful impropriety. ${ }^{\prime i}$ As a play theorist whose work focuses on the cultural significance of play in human life, he describes body play in a way that encompasses the kind of intimacies later embedded in Goethe's Römische Elegien (1795; Roman Elegies) and Epigramme. Venedig 1790 (1796; Epigrams. Venice 1790). Within the nexus of the generative language and erotic pleasure in Goethe's sexualized poetics, however, the creative moment gives a purpose to play that exceeds the theoretical and tactile frame of Sutton-Smith's study.

i. Brian Sutton-Smith, "Play and Ambiguity," in The Game Design Reader: A Rules of Play Anthology, ed. Katie Salen and Eric Zimmermann (Cambridge, MA: MIT Press, 2006), 296-313, here 299. 
Spiel in Adelung's Wörterbuch der hochdeutschen Mundart: In engerer und theils figürlicher Bedeutung ist das Spiel eine Bewegung und Beschäftigung, welche aus keiner andern Absicht als zum Zeitvertreibe oder zur Ergetzung des Gemüthes unternommen wird. (a) Im weitern Verstande, wo alle Beschäftigungen dieser Art Spiele genannt werden können.'

In a rather strict and partially more figurative sense, play or the game is a movement and activity that is undertaken for no other purpose than passing time or delighting the mind. (a) In the broader sense where all activities of this kind can be called games or play.

i. Johann Christoph Adelung, Grammatisch-kritisches Wörterbuch der Hochdeutschen Mundart: mit beständiger Vergleichung der übrigen Mundarten, besonders aber der Oberdeutschen, ed. Franz Xaver Schönberger, 2nd rev. ed., 4 vols. (Vienna: B.Ph. Bauer, 1811), 1:807-08.

to be lost with him and then reconfigured as a couple in the cosmic motion of the ensuing waltz. When an approaching thunderstorm interrupts the pleasures of this new, erotically charged dance and its unsettling affective storm, however, Spiel returns as a figure of thought in Werther's recollection to feature Lotte as the mistress of ceremonies in a scene that rescues the unsettled crowd from their growing fear of the imminent danger, which has threatened to bring the pleasures of the evening to an abrupt end: "Wir spielen Zählens! sagte sie" (FA 1.8:53; Let's play a counting game, she said). In uncanny anticipation of both the mathematical and dynamical sublime in Kant's third critique, Lotte conquers her own dread, as well the dread of her fellow dancers, by staging a game. The increased pace that overtakes fear connects this moment to the concept veloziferisch, as Bryan Norton writes: "Veloziferisch describes motion at a speed that has surpassed that of Bildung-of organic, healthy motion." ${ }^{17}$ By having everyone tally numbers with increasing velocity, she provokes hesitation and confusion, which in turn produces a number of breakdowns in the counting and "punishing" smacks across the faces of the failed counters, including Werther, who relishes his slap as the hardest one of all. Before the tally can reach one thousand, however, the once fearful group-recoiling from the pleasurable pain-reconstitutes itself in laughter, and the fictional couple can experience the overwhelming power of nature (and their shared erotic attraction) from a safe distance. Lotte's Spiel thus serves a serious purpose in this exemplary scene by managing the emotional extremes of fear and desire, while also enabling human contact. Accordingly, a second playful mise-en-scène of the sublime immediately follows in the couple's shared homage to the poet Klopstock, whose ode "Frühlingsfeier" (1771; Celebration of Spring) had become a rallying call for the counterculture of the younger generation.
Goethe's association of play and violence was not limited to the slaps that he staged in his first novel or its representations of nature's destructive power, however. More ominously, he also came to understand war as spectacle and play. By describing the theater of battle as a "schreckliches Spiel" (FA 1.8.884; frightening game) in "Achilleis" (1797-1799/1808), for example, he was able to equate its destruction with the inner turmoil of hatred. And references that configure the battlefield as spectacle and experiment abound throughout his works in ways that complement a 1792 composition by the Weimar artist Georg Melchior Kraus of a military encampment with two sets of spectators: a grouping of three seated women with protective parasols and two men standing behind them with surveying equipment (Fig. 1).

In an autobiographical account of the siege of Mainz (1822), Goethe corroborates his notion of war as play (in the sense of spectacle) in words that recall the language of the epic fragment "Achilleis" and its portrayal of personal wit-

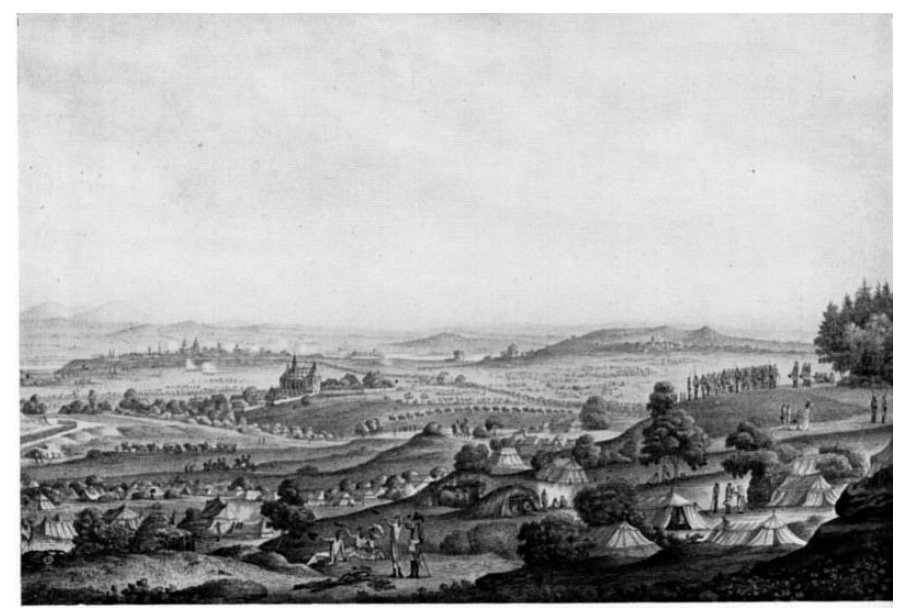

Fig. 1. Hans Wahl and Anton Kippenberg, Goethe und seine Welt (Leipzig: Insel-Verlag, 1932), 132. 
ness: "Wir sahen auf der Schanze vor Marienborn diesem schrecklichen Schauspiele zu" (FA 1.16:585; We observed this terrifying spectacle from the entrenchment at Marienborn), he writes in his dairy on the night of June 28, 1793.

[E]s war die sternenhellste Nacht, die Bomben schienen mit den Himmelslichtern zu wetteifern, und es waren wirklich Augenblicke, wo man beide nicht unterscheiden konnte. (FA 1.16:585)

$[\mathrm{I}] \mathrm{t}$ was the brightest starry night, the bombs appeared to be competing with the lights in the sky, and there were truly moments when the two could not be distinguished from each other.

And, near the end of the same entry, he repeats the figure, which now explicitly connects Spiel-in the manner of Kant's analysis of the sublime in nature-with the threatening chaos of the battlefield, on the one hand, and the safety of the observers' distance from it, on the other:

Man konnte sich dieses Schauspiel sehr bequem verschaffen, wenn man sich der nächsten Höhe etwas seitwärts außer der Richtung der Kugel stellte, unter sich dieses wunderliche Gewimmel sah und die Kugel an sich vorbeisausen hörte. (FA 1.16:589)

You could get access to this play [spectacle] very comfortably, if you positioned yourself on the higher level, a bit sideways and beyond the range of the bullets, and observed this bizarre commotion beneath you and heard the bullets zooming past.

Goethe thus connects Spiel and Schauspiel to the experience of war, sometimes in the repose of spectatorship, but also (like Werther) at times, entering the play, or the violent theater of war, himself in the manner of the Kantian sublime.

Yet another metaphorical use of Spiel, which allows Goethe to explore the philosophical implications of the vicissitudes of fate more explicitly than its staging as a figure of thought for war, can be found in descriptions of gambling and public gaming. David G. Schwartz, in his history of gambling, charts the influence of macro-economic change on the transition from personal, social entertainment to the industrial model of play at the cusp of capitalism's creation of the casino and public profit. ${ }^{18}$ Interestingly, Schwartz's narrative, which moves from the early casinos in Europe to Las Vegas, appears to have been anticipated by Goethe. When reporting from Frankfurt on August 19, 1797, on the rise of roulette as a consequence of the French Revolution and its violent aftermath on both sides of the Rhine, for example, he links this prototypical game of chance to the disruptive realities of the political upheavals:

Von dem großen Spiel, das die Zeit her hier gespielt worden, hört man überall reden. Es gehört diese Seuche mit unter die Begleiter des Kriegs, denn sie verbreitet sich am gewaltsamsten zu den Zeiten, wenn großes Glück und Unglück auf der allgemeinen Wagschale liegt; wenn die Glücksgüter ungewiß werden, wenn der Gang der öffentlichen Angelegenheiten schnellen Gewinst und Verlust auch für Particuliers erwarten läßt. (WA 1.34:250)

Everywhere you can hear people talking about the great game that was being played here back then. This plague belongs to those who accompany war, for it spreads most violently at times when great fortune and misfortune lie on the common scale; when possessions won by chance become uncertain, when the course of public affairs creates the expectation of quick profit and loss, even for independent gentlemen.

The vicissitudes of war and its gamble with life and death permeate the private sphere and shape individual behavior to such an extent that even those "independent gentlemen" in a position to purchase a title from the emperor fall prey to the contingencies of the game. ${ }^{19}$ Goethean Spiel, in these passages, connects a vocabulary of disease with an anti-theological vision of fate. Linking games of chance with a roll of the dice that determines who will live or die during times of war, he ironically indicts Spielsucht (compulsive gambling) and in turn suggests a kinship with Schiller's play drive and G.E Lessing's popular Lustspiel (comedy), Minna von Barnhelm oder Das Soldatenglück (1767; Minna von Barnhelm or the Luck of Soldier), which Goethe knew and praised. On Lessing's stage, the luck of the soldier is played against the luck of losing and then winning back a personal fortune, as well as the rising and falling fortunes 
of love. More than three decades later, in fact, Goethe would return to the same playful constellation of "luck with the ladies" in a fictional dialogue that opposes two models of masculinity. In "Die guten Frauen, als Gegenbilder der bösen Weiber, auf den Kupferbildern des diesjährigen Almanachs" (1799; FA 1.8:610-34; Good Ladies represented in Opposition to Bad Females on the Copper Plates of this Year's Almanac), two male figures enjoy either "Glück bei den Weibern" (FA 1.8:61; luck with the ladies), as Carrando does, or "im Spiel" (FA 1.8:617; with gambling), as Ferrando. ${ }^{20}$ In Goethe's universe, then love, war, and gambling are all games of chance that, like the play of Schauspiel, extend the realm of the metaphor to include being. For Goethean play, nothing less than human existence is at stake.

\section{Spiel as Performance}

In numerous critiques of contemporary drama, Goethe demonstrates a keen awareness of the range of meaning in the lexeme Spiel, including its extension to the language of role-playing in its essential relation to being. In his understanding of literature and its existential import, moreover, which reflects another of Adelung's definitions, he also anticipates Judith Butler's association of performativity and gendered identity.

In his letters to Charlotte von Stein, which abound in wordplay as well as reports about social and existential play, Goethe also often undertakes excursions into drama and dramatic play. Writing from Wörlizt on May 14, 1777, he reports,

[m]it den Menschen hab ich, wie ich spüre weit weniger Verkehr als sonst. Und ich scheine dem
Ziele dramatischen Wesens immer näher zu kommen, da michs nun immer näher angeht wie die Grosen mit den Menschen, und die Götter mit den Grosen spielen. (FA 2.2:130)

I sense I have far less human intercourse than usual. And I seem to get closer to the goal of a dramatic existence in that I am increasingly concerned with how the great play with people and the gods play with the great.

So often, play with power and wordplay center Goethe's dramatic practice. And in another letter, written between October 31 and November 3, 1777, he describes in similar terms circumstances that have not only entertained him and stimulated his creativity, but also distracted him. Only now he is the "rolling" object that is being played:

Die Welt ist so lachend und die Gegend so frey dass ich wieder zeichnen würde, wenn die Umstände nicht wieder Ball mit mir spielten. Ich bin wie der Komet im Spiel den man zu allen Karten macht. (FA 2.2:144)

With the world laughing as it is and my surroundings so free, I would draw again, if only my circumstances had not again played ball with me. I am like the Komet in the game that can be used for any card.

In the eighteenth-century card game Komet, the nine of diamonds could be assigned any value. As the wild card a game with which he identifies, Goethe appears to be suggesting that, under certain circumstances, he can

Another definition in Adelung's Wörterbuch: Die nach gewissen Regeln eingerichtete Nachahmung menschlicher Handlungen so fern diese zur Belustigung anderer dienet. Im Oberdeutschen sagt man daher noch, in das Spiel gehen. Allein im Hochdeutschen ist es für sich allein veraltet. Desto gangbarer ist es hingegen in den Zusammensetzungen Schauspiel, Trauerspiel, Lustspiel, Vorspiel, Nachspiel, Zwischenspiel, Possenspiel, Singspiel, Schäferspiel, u.s.f. (197-98)i

The imitation of human actions arranged according to certain rules, so that they serve to amuse others. In Upper German one therefore one still says, to go to the play; only in High German is this out-of-date. More common, however is its use in the composite nouns drama, tragedy, comedy, prelude, postlude, interlude, farce, melodrama, pastoral, etc. 
self-reflexively play himself in accord with the rules of a game that, like Schiller's Spieltrieb, encourages the reciprocal play of desire and constraint.

In this context, play allows Goethe to situate his courtly duties and personal inclinations and ambitions on the cusp of authenticity. He acknowledges this in a letter written from Eisenach on December 10, 1781, that reflects on the time he has spent with the young Duke and his entourage:

Der Herzog thut was unschickliches mit dieser Jagd, und doch bin ich nach seiner Herzoglichkeit mit ihm zufrieden. Die andern spielen alle ihre Rollen. Ach Lotte wie lieb ist mirs daß ich keine spiele. Ich lasse mich als Gast tracktiren und lasse mir als einem Fremden klagen, es geht nichts besser und nichts schlimmer als sonst, ausser daß der Herzog weit mehr weis was er will, wenn er nur was bessers wollte. (FA 2.2:392)

The Duke is doing something improper with this hunt, and yet I am still content with his nobility. The others all play their roles. Alas, Lotte, how happy I am to play none. I allow myself to be mistreated and be deplored an outsider, it is not better or worse than usual, except that the Duke only knows what he wants, if he only wanted something better.

Goethe, in his epistolary confession to Charlotte, cringes at the social roles others play. In fact, he protects himself from the subservient role he, too, must play; it confirms his sense of self. The binary between work and play here collapses in his assertion of a core identity.

In the Italienische Reise (1816; Italian Journey), Goethe continues to consider the competing influences of play and place/displacement on his thinking by returning to the existential configuration of Spiel as a form of gambling. In another letter to Frau von Stein written from Rome on January 20, 1787, he justifies his trip and his search for an artistic life:

Dazu kann ich nichts weiter sagen als: ich habe nur Eine Existenz, diese hab ich diesmal ganz gespielt und spiele sie noch. Komm ich leiblich und geistlich davon, überwältigt meine Natur, mein Geist, mein Glück, diese Krise, so ersetz ich dir tausendfältig was zu ersetzen ist. - Komm ich um, so komm ich um, ich war ohne dies zu nichts mehr nütze. (FA 2.3:229-30)
To that, I can say no more than this: I have but one existence, and this time I have played it completely and I am playing it still. If I survive physically and spiritually, if my nature, my mind, or my good fortune overcomes this crisis, then I will replace what I owe you a thousandfold. - If I die, then I die, without this I was of no further use.

For Goethe, the precarious state of human existence constitutes one facet of play. Life is as fickle as the games that make things happen. But his sense of exposure and vulnerability to the vicissitudes of his own desire, together with his willingness to entertain risk, also helped him craft new meanings for Spiel. While Goethean Spiel, understood as performance or public play and display, is itself no less fickle than the life it enables, then, Goethe often deployed forms - from carnival to gallows - that celebrate or mark the role of unaccountability in the very public spaces their play establishes.

\section{The Pleasures of Play}

Writing from Venice in 1786, Goethe recalls an early gift from his father's Italian travels:

Wie die erste Gondel an das Schiff anfuhr, fiel mir mein erstes Kinderspielzeug ein, an das ich vielleicht in zwanzig Jahren nicht mehr gedacht hatte. Mein Vater hatte ein schönes Gondelmodell von Venedig mitgebracht, er hielt es sehr sehr werth und es wurde mir hoch angerechnet wenn ich damit spielen durfte. Die ersten Schnäbel von Eisenblech, die schwarzen Gondelkäfige, alles grüßte ich wie eine alte Bekanntschafft, wie einen langentbehrten ersten Jugend Eindruck. (FA 2.3:82)

As the first gondola approached the ship, I remembered the first toy of my childhood, which I had probably not thought of for twenty years. My father had brought back for me from Venice a beautiful model of a gondola that he considered to be quite valuable, and I was thought highly of, if I were permitted to play with it. The first prows made from sheet iron, the black gondola-cages, all of that welcomed me like an old acquaintance, like a long-absent impression from my youth. 
The memory of his first Kinderspielzeug (childhood toy) resurfaces in Goethe's mind after twenty years of absence. The precious model of a gondola, a gift from his father, introduces his initial impression of Venice, thereby making this strange new place seem familiar and personal. This otherwise innocuous and long forgotten thing of play allows a self in flight, or subject on the move and in transition, to encounter a past self, while conferring pleasure and familiarizing the unknown. From his childhood toy and paternal gift, then, which he rediscovers in Italy, to the playful arabesques he observes in certain Italian paintings and even the yo-yo in the ninetieth Venetian Epigram, the poet associates things that belong to the material culture of play with the figure of fortune's wheel and the exigencies of divine and natural agency that it implies. In a sharp departure from the conventional understanding of the lexeme Spiel that the definitions in Adelung comprise, Goethe extends the sematic range of the pleasures of play to include freedom, emotional heights, and physical enjoyment. From things he had collected and then years later offered as gifts to his son and grandchildren, through magic tricks and card games, as well as puppet plays, masques, and amateur theater productions, to scenes of flirting and seduction, Goethe's explorations of the full semantic range of play are informed by an extensive range of pleasurable moments as well that move from the erotic to the aesthetic through to the cognitive.

The most famous literary example of this kind of playful transition can be found in the celebrated distischon from the seventh of Goethe's "Römische Elegien" (1786-1788/1795; Roman Elegies):

Oftmals hab ich auch schon in ihren Armen gedichtet Und des Hexameters Maß leise mit fingernder Hand, Ihr auf den Rücken gezählt. (FA1.1:407)

Often I would even write poems in her embrace, counting hexameter beats out on her back softly with my fingering hand. ${ }^{21}$

Here the tapping fingers of the poet's hand publicize two intimate moments of creative and erotic proximity by playing with a highly variable form of structured verse from ancient didactic poetry that his elegy displaces and reinvents as a new kind of "pedagogy." Metonymically reconfigured as the tactile image of tapping and gliding fingers that are either gently pressed into the naked back of his beloved in the measured beats of the ancient distichon or move down her side from breast to hip in search of the essence of form, the poet's body, together with that of the sleeping woman beside him, becomes an instrument played by this poem in the making. And in this spirit the poet's tapping, gliding, and, ultimately, toying hand is also called "geschäftig" (busy) and "sehend" (seeing or watchful). Through the course of these various inflections, Goethe's nighttime play world has become a site of transfiguration where, like the aeolian harp in the "Zueignung" (Dedication) to Faust, his own reconfigured hand, conjoined with his lover's body as an instrument of play, has acquired an agency of its own. ${ }^{22}$

In poem ninety from the cycle Epigramme. Venedig 1790 (1796; Epigrams. Venice 1790), Goethe continues his erotic itinerary by featuring a trendy toy that replicates his exploratory sexual adventures. In brief lines about longing, nocturnal loneliness, and the religion of the Nazarene, a yo-yo appears as an accessory of love:

Welch ein lustiges Spiel! Es windet am Faden die Scheibe, Die von der Hand entfloh, eilig sich wieder herauf! Seht, so schein ich mein Herz bald dieser Schönen, bald jener Zuzuwerfen; doch gleich kehrt es im Fluge zurück. (WA 1.1:328)

What a merry game! The disc on a string that escaped my hand winds itself up again! Look, that's how I seem to cast my heart, sometimes to this beauty, sometimes to that one; but it returns immediately in flight. ${ }^{23}$

As Browne and Davis first suggested,

even as early as 1790, before the full strength of the fad hit Europe generally, Goethe must have been aware of [the yo-yo's] existence and popularity. The conjugation of Goethe's general propensity for keeping well-informed and the wide-spreadness of the cult of the yo-yo, plus the various literary comments the phenomenon elicited, lead to the inevitable conclusion that Goethe must have known the yo-yo. ${ }^{24}$

The toy's configuration in Goethe's two distichons as a fickle heart that is cast and comes back has been variously interpreted with reference to both Charlotte von Stein and Christiane Vulpius. ${ }^{25}$ While the playful hand that engages in an affectionate game of "fort/da" 
with the yo-yo may be performing an erotic legerdemain, however, the object in play also recalls the aristocratic French emigres with targets on their heads who played with yo-yo's while awaiting execution. The Spielzeng thus connects material culture, physical desire, bourgeois masculine identity, and political violence all in play.

In examples from both his biographical and fictional prose, then, Goethe accounts for the pleasure of spectacle and games in vocabularies that evoke a range of experiences from the anthropological and ethnographic to the erotic. ${ }^{26}$ In the farce Das Jahrmarktsfest zu Plundersweilern (1773/1778; The Festival Fair at Plunderweilern), Goethe cast himself in the carnival role of the Marktschreier, whereas the plot his comedy Die Mitschuldigen (1763/1783; The Complicit), which features a hopeless gambler, a reluctant wife, her former lover, and a victim of theft, is driven by gaming, desire, and deception. In the story from Unterhaltungen deutscher Ausgewanderten (1795; Conversations of German Refugees), "Der Prokurator," who is the protagonist, returns to his Italian homeland to find his hometown in the midst of a festival, with games and competitions taking place in a public square. Social games lead to erotic encounters. The observation of public performance, such as the acrobat Bettina who appears in the Venetian Epigrams, focuses the reading experience of play and display: the observer coyly acknowledges her flexibility and appeal, yet wants to protect the performer from the male gaze. In the marketplaces of his prose and poetry, Goethe locates public performances of sanctioned play.

Arguably, the quintessential Goethean text of Spiel as metaphor, performance, and pleasure is Faust. The protagonist's quest for experience, facilitated by the lord of negation as master of ceremonies, runs the gamut of play as magic, prank, seduction, war, poetry, public festival, and natural spectacle, not to mention the Lord's bet with Mephistopheles or Faust's subsequent pact, which puts the human soul in jeopardy. Irony, of course, short circuits any stable interpretation of Goethe's magnum opus, which Hegel would call an "absolute philosophical tragedy." But there are also many earnest moments throughout that are equally playful and thus support Goethe's remark in an 1832 letter to Wilhelm von Humboldt that the second part of Faust is nothing more than a series of "ernste Scherze" (FA 2.11:550; serious jokes). The same formulaic description could also easily be applied to scenes in Part I, however, including the bedroom scene of the so-called Gretchen Tragedy, where Faust, overcome with desire for Margarete, sets scruples aside and relies on devilry to bribe her affection. In the following passage, which configures Gretchen in terms of her child-like innocence and play, Mephistopheles exposes the limits of his power:

Hier ist ein Kästchen leidlich schwer, Ich hab's wo anders hergenommen. Stellt's hier nur immer in den Schrein, Ich schwör Euch, ihr vergehn die Sinnen; Ich tat Euch Sächelchen hinein, Um eine andre zu gewinnen. Zwar Kind ist Kind, und Spiel ist Spiel. (FA 1.7:117.2731-37)

Here's a small chest that's a little heavy, I took it from somewhere else, just put it there into the cupboard. I swear to you, she will faint; I put some trifles in there for you, to conquer another. For sure: a child is a child, and play is play.

Gender, Genre, and Figures of Play: The designation "Eine Tragödie" (a tragedy, or one tragedy) on the titlepage of Faust suggests that its stage is the stage of a (certain kind of tragedy). In this regard, Goethe's work is "deadly serious," as all tragedies must be. Despite its penetrating exploration of human error and suffering, however, or perhaps because of the insights it inspires into the condition of being human, this unorthodox tragedy also never ceases to be playful. From Gretchen's bedchamber early in Part One through the chaotic cosmic stage of "Mountain Gorges" at the end of Part Two, the theatrical spectator witnesses one grand serialized staging of the play of the masculine and the feminine. But in an odd reversal of the gender culture of his day, Goethe's tragedy ultimately understands the male principle-which is conceptualized in Faust's endless striving (or his conatus to persist in his own being) - to be at greater risk in his high stakes game than the generative and redemptive female principle - which is more closely associated with intercessional agency and has 
the power to influence the masculinized divine. The gender play of Goethe's great philosophical work thus ends by reconfiguring the "Lord" of the "Prologue in Heaven" as "The Eternal-Feminine." In the great celebration of the work's final scene and lines, Gretchen becomes part of the essential process of figurative play and redemption.

Mephistopheles's biting lines, which will not be the last ones that feature him as maître des jeux (master of ceremonies or games), point to a shift in Goethean Spiel. Throughout the rest of Faust, in fact, play will continue to be sexualized and linked to seduction, thereby also ensuring that questions of gender will remain central in the ongoing staging of the concept.

With the celebrated Blumenwort (flower-word) episode in the scene "Martha's Garden," where Gretchen plays a children's game originally called "effeuiller la marguerite," or "pluck the daisy," in the hope of divining the feelings of her beloved, Goethe stages a game with a flower that becomes a play of words that in turn plays out the transformative power of language to release the redemptive power of love in the midst of a succession of violent and destructive acts. This game, familiar as 'he loves me, he loves me not,' is typically played by plucking the petals from a flower's corolla while assigning a positive or negative value to each pluck. As implied by the name of the original French game, the flower destined to suffer this abuse is a daisy or, in German, a "Margarete." In the scene where Goethe's Margarete plays this game, however, the stage direction identifies the flower as a "Sternblume" (star flower), which in English is the blue alpine daisy. This play of names and play of flower varieties is significant, firstly, because it suggests that the violence suffered by the "Margarete" qua "Sternblume" is part of a process of redemptive transformation as well. Secondly, it shows how Goethean play works within the Faust-tragedy as a bridge that connects the small world of Part One to the large world of Part Two, including its final scene of transformative redemption. Thus, when Faust asks Gretchen what she is doing and she dismisses her act"Nein, es soll nur ein Spiel" (FA 1.7:136.3180; No, it is supposed to be only a game) - the performative language of the playful game ultimately makes Gretchen complicit in murder and infanticide: it will result in her own beheading. In the words of the "Evil Spirit" who plagues her conscience as the "Dies Irae" resounds in the cathedral, Gretchen's downfall, at least at this point in her dramatic development, appears to be a case of play gone wrong:

Wie anders, Gretchen, war dir's, Als du noch voll Unschuld Hier zum Altar tratst Aus dem vergriffnen Büchelchen Gebete lalltest, Halb Kinderspiele, Halb Gott im Herzen! Gretchen! Wo steht dein Kopf? In deinem Herzen Welche Missetat? (FA 1.7:164.3776-86)

How different you were, Gretchen, when you came before the altar full of innocence, babbling prayers from a little old booklet no longer in print, half child's play, half God in your heart! Gretchen! Where is your head? What misdeed in your heart?

Neither God nor children's games can protect Margarete's innocence any longer. As Goethe continues to propel Faust through a long series of pranks, plots, counterrevolutions, seductions, manipulations, senile visions, and death, however, only to resurrect the game of his masculinity in a redemptive play of gender with the "Eternal-Feminine," the full range of Goethean Spiel emerges as the "tragedy" ends. If Faust's gamble can fail or the Lord's bet with Mephistopheles be lost, if creativity can result in destruction and the beautiful to yield to the monstrous - all these opposites can also productively coexist within play. Ultimately, Goethe's reconceptualized Spiel resists systematic definition. But it also preserves a productive tension in the high-stakes game of love and death. 


\section{Notes:}

${ }^{1}$ For examples, see the description of this work on the publisher's website.

${ }^{2}$ Pierre Bertaux, Gar schöne Spiele spiel’ ich mit dir! Zu Goethes Spieltrieb (Frankfurt a.M.: Insel, 1986), 10. Translations, unless noted, are my own.

${ }^{3}$ See Scott G. Eberle, "The Elements of Play: Toward a Philosophy and a Definition of Play," American Journal of Play, 6, no. 2 (Winter 2014): 214-33.

${ }^{4}$ Emphasis in the original.

${ }^{5}$ For references to Goethe's relationship to Kantian philosophy, see Anthony K. Jensen, "Johann Wolfgang von Goethe (1749-1832)" Internet Encyclopedia of Philosophy. Accessed January 24, 2021.

${ }^{6}$ Johan Huizinga, Homo Ludens: A Study of the Play Element in Culture (Boston: Beacon, 1950), iv. See also Thomas S. Henricks, Play and the Human Condition (Urbana: U of Illinois P, 2015).

${ }^{7}$ Ebook collection (EBSCOhost, accessed January 22, 2018).

${ }^{8}$ See, for example, the work of Ingeborg Weber-Kellermann, Die Kindheit. Eine Kulturgeschichte (Frankfurt a.M.: Insel, 1997); Die Kinderstube (Frankfurt a.M.: Insel, 1991); and Die Kindheit: Kleidung und Wohnen, Arbeit und Spiel: Eine Kulturgeschichte (Frankfurt a.M.: Insel, 1979). In the former, Weber-Kellermann provides a narrative of childhood cultures from the Middle Ages through the postwar period, with attention to class difference and intersectionality in children's identities.

${ }^{9}$ Immanuel Kant, Critique of Judgement, trans. and analytical indexes by James Creed Meredith (Oxford: Oxford UP, 1991), 165.

${ }^{10}$ Friedrich Schiller, Vierzehnter Brief, in On the Aesthetic Education of Man in a Series of Letters, ed. and trans. Elizabeth M. Wilkinson and L.A. Willoughby (Oxford Clarendon Press, 1967), 96. Subsequent references to this edition appear in parentheses.

${ }^{11}$ Friedrich Schiller, Schillers Leben in Briefen, ed. Helmut Koopmann (Weimar: Hermann Böhlaus Nachfolger, 2000), 497.

${ }^{12}$ See the entry for "Spiel" in Jacob and Wilhelm Grimm, Deutsches Wörterbuch, ed. Berlin-Brandenburgische Akademie der Wissenschaften and Akademie der Wissenschaften zu Göttingen, 33 vols. (Leipzig and Munich: S. Hirzel and Deutscher Taschenbuch Verlag, 1854-1972), 16:2275. Enter "Spiel" in the search box at https:// woerterbuchnetz.de/?sigle=DWB.

${ }^{13}$ See the preceding note for the Kant-citation in the entry "Spiel" in Grimms' Deutsches Wörterbuch, 16:2275. https://woerterbuchnetz.de/?sigle=DWB. It occurs immediately after the Goethe citation.

${ }^{14} \mathrm{My}$ thanks to Clark Muenzer for this suggestion and substantive feedback on earlier versions of this entry.

${ }^{15}$ See also Robin Rehm, "Bild und Erfahrung. Goethes chromatisches Kartenspiel der 'Beiträge zur Optik' von 1791," Zeitschrift für Kunstgeschichte, 72, no. 4 (2009): 497-518.

${ }^{16}$ For the translation, I consulted: Goethe, Die Leiden des jungen Werther / The Sorrows of Young Werther, bilingual edition, trans. R. Dil- lon Boylan, ed. Karl-Maria Gut (Leipzig 1774/1777; HA 1948; Neuausgabe Berlin 2018), 14-15.

${ }^{17}$ Bryan Norton, "Veloziferisch (Velociferian)," Goethe-Lexicon of Philosophical Concepts 1, no. 1 (2021).

${ }^{18}$ David G. Schwartz, Rolling the Bones: The History of Gambling (Las Vegas, NV: Winchester, 2006).

${ }^{19}$ For the use of this term with reference to Frankfurt, see Todd Kontje, Imperial Fictions: German Literature Before and Beyond the $\mathrm{Na}$ tion-State (Ann Arbor: U of Michigan Press, 2018), 107-99.

${ }^{20}$ Johann Wolfgang von Goethe, "Die guten Frauen, als Gegenbilder der bösen Weiber, auf den Kupferbildern des diesjährigen Almanachs" (1799). Last accessed January 24, 2021.

${ }^{21}$ I consulted the edition of Goethe, Erotic Poems, trans. David Luke, intro. Hans Rudolf Vaget (Oxford: Oxford UP, 1988), 14; translation 15 (Luke's rendition modified). This edition numbers the epigram 37.

${ }^{22}$ Goethe, Erotic Poems, Roman Elegies, here VII, original 14; translations 15. Citations include my insertions to emphasize repetition of the word "hand."

${ }^{23}$ Designated epigram thirty-seven in this collection, 92 in Goethe, Erotic Poems, Venetian Epigram, 93.

${ }^{24}$ Richard J. Browne and M.C. Davis, "Goethe and the Yo-Yo." Modern Language Quarterly 14, no. 1 (March 1953): 98-101, here 101.

${ }^{25}$ Elisabeth Böhm, Epoche Machen. Goethes Konstruktion der Weimarer Klassik zwischen 1786 und 1796. Diss. U of Bayreuth, 2010. The dissertation focuses on the origin and publication history, with attention to contemporary politics briefly considered (206). Many focus on the relationship between political upheaval, erotic exploration, and the modernizing of classical form. See, for example, Hans Jürgen Scheuer, Manier und Urphänomen. Lektüren zur Relation von Erkenntnis und Darstellung in Goethes Poetologie der "geprägten Form" (Würzburg: Königshausen \& Neumann, 1996). Reiner Wild argues in Goethes klassische Lyrik (Stuttgart: Metzler, 1999) that Goethe's classical poetry was "Teil und Ausdruck des 'Projekts Klassik," or a process of aesthetic reconciliation between modernity and antiquity. See also Horst Lange, "Goethe's Strategy of Self-Censorship: The Case of the Venezianische Epigramme," Monatshefte 91, no. 2 (1999): 224-40 and Stephan Oswald, Früchte einer großen Stadt-Goethes Venezianische Epigramme (Heidelberg, Winter, 2014).

${ }^{26}$ Michael Saman, "Towards Goethean Anthropology: On Morphology, Structuralism, and Social Observation," Goethe Yearbook 27 (2020): 137-63.

\section{Related Entries in the GLPC}

Beispiel (example), Einbildungskraft (Power Of The Imagination), Phantasie (Fantasy), Puppenspiel (Puppet Theater), Rollen Spielen (Play Roles), Schauspiel (Play), Spielen (To Play), Spieltrieb (Play Drive), Streiche Spielen (Play Tricks). 


\section{Works Cited and Further Reading}

Adelung, Johann. Grammatisch-kritisches Wörterbuch der Hochdeutschen Mundart: mit beständiger Vergleichung der übrigen Mundarten, besonders aber der Oberdeutschen. Edited by Franz Xaver Schönberger, 2nd rev. ed., 4 vols. Vienna: B.Ph. Bauer, 1811.

Benjamin, Walter. "Die frühromantische Kunsttheorie und Goethe." In Der Begriff der Kunstkritik in der deutschen Romantik. Abhandlungen, Gesammelte Schriften 1.1:110-22. Edited by Rolf Tiedemann and Hermann Schweppenhäuser. Frankfurt a.M.: Suhrkamp, 1991.

Bertaux, Pierre. Gar schöne Spiele spiel' ich mit dir! $Z u$ Goethes Spieltrieb. Frankfurt a.M.: Insel, 1986.

Böhm, Elisabeth. Epoche Machen. Goethes Konstruktion der Weimarer Klassik zwischen 1786 und 1796. Diss. U of Bayreuth, 2010.

Browne, Richard J. and M.C. Davis, "Goethe and the Yo-Yo." Modern Language Quarterly 14, no. 1 (March 1953): 98-101.

Eberle, Scott G. "The Elements of Play: Toward a Philosophy and a Definition of Play." In American Journal of Play, 6, no. 2 (Winter 2014): 214-33.

Grimm, Jacob and Wilhelm. Deutsches Wörterbuch. Edited by the Berlin-Brandenburgische Akademie der Wissenschaften and the Akademie der Wissenschaften zu Göttingen, 33 vols. Leipzig and $\mathrm{Mu}-$ nich: S. Hirzel and Deutscher Taschenbuch Verlag, 1854-1972.

Henricks, Thomas. Play and the Human Condition. Urbana, Chicago, and Springfield: U of Illinois, 2015.

Hexter, Ralph. "Poetic Reclamation and Goethe's Venetian Epigrams." MLN96, no. 3 (1981): 526-55.

Huizinga, Johan. Homo Ludens: A Study of the Play Element in Culture. Boston: Beacon, 1950.

Kant, Immanuel. Critique of Judgement. Translated by James Creed Meredith. 13th impression. Oxford: Oxford UP, 1991.

-. Werkausgabe. Edited by Wilhelm Weischedel, 20 vols. Frankfurt a.M.: Suhrkamp, 1968.

Kayser, Wolfgang. Kunst und das Spiel. Fünf Goethe-Studien. Göttingen: Vandenhoeck \& Ruprecht: 1961.
Lacoue-Labarthe, Philipe and Jean-Luc Nancy. The Literary Absolute: The Theory of Literature in German Romanticism. Translated by Philip Barnard and Cheryl Lester. Albany: SUNY Press, 1988. Originally published as L'absolu litteraire. Paris: Editions du Seuil, 1978.

Lange, Horst. "Goethe's Strategy of Self-Censorship: The case of the Venezianische Epigramme." Monatshefte 91, no. 2 (1999): 224-40.

Moore, Evelyn K. The Eye and the Gaze: Goethe and the Autobiographical Subject. Bern: Peter Lang, 2015.

Oswald, Stephan. Früchte einer großen Stadt-Goethes Venezianische Epigramme. Heidelberg: Winter, 2014.

Rehm, Robin. "Bild und Erfahrung. Goethes chromatisches Kartenspiel der 'Beiträge zur Optik' von 1791." Zeitschrift für Kunstgeschichte 72, no. 4 (2009), 497-518.

Saman, Michael. "Towards Goethean Anthropology: On Morphology, Structuralism, and Social Observation." Goethe Yearbook 27 (2020): 137-63.

Scheuer, Hans Jürgen. Manier und Urphänomen. Lektüren zur Relation von Erkenntnis und Darstellung in Goethes Poetologie der "geprägten Form." Würzburg: Königshausen \& Neumann, 1996.

Schiller, Friedrich. On the Aesthetic Education of Man in a Series of Letters. Edited and translated by Elizabeth M. Wilkinson and L.A. Willoughby. Oxford: Clarendon Press, 1967.

-. Schillers Leben in Briefen. Edited by Helmut Koopmann. Weimar: Hermann Böhlaus Nachfolger, 2000 .

Schreiber, Elliott. "Narcissus at Play: Goethe, Piaget, and the Passage from Egocentric to Social Play." In Play in the Age of Goethe: Theories, Narratives, and Practices of Play around 1800, edited by Edgar Landgraf and Elliott Schreiber, 117-42. Lewisburg, PA: Bucknell UP, 2020.

Schwartz, David G. Rolling the Bones: The History of Gambling. Las Vegas, NV: Winchester, 2006.

Simpson, Patricia Anne. “'Wo die Ironie erscheint:' Tieck als Herausgeber in Den Jahrbücher-Rezensionen." In Die Jahrbücher für wissenschaftliche Kritik. Hegels Berliner Gegenakademie, edited by Christoph Jamme, 301-20. Stuttgart: frommann-holzboog, 1994. 
-. The Play World: Toys, Texts, and the German Transatlantic Childhood. University Park, PA: Pennsylvania State UP, 2020.

-. "Playthings: Goethe's Favorite Toys." In Play in the Age of Goethe: Theories, Narratives, and Practices of Play around 1800, edited by Edgar Landgraf and Elliott Schreiber, 143-172. Lewisburg, PA: Bucknell UP, 2020.

Sutton-Smith, Brian. "Play and Ambiguity." In The Game Design Reader: A Rules of Play Anthology, edited by Katie Salen and Eric Zimmermann, 296-313. Cambridge, MA: MIT Press, 2006.
Weber-Kellermann, Ingeborg. Die Kindheit. Eine Kulturgeschichte. Frankfurt a.M.: Insel, 1997.

-. Die Kinderstube. Frankfurt a.M.: Insel, 1991.

-. Die Kindheit: Kleidung und Wohnen, Arbeit und Spiel: Eine Kulturgeschichte. Frankfurt a.M.: Insel, 1979.

Wild, Reiner. Goethes klassische Lyrik. Stuttgart: Metzler, 1999.

Žižek, Slavoj. The Indivisible Remainder: On Schelling and Related Matters. London: Verso, 1996. 